\title{
Transcellular Activation of Platelets and Endothelial Cells by Bioactive Lipids in Platelet Microparticles
}

\author{
Orla P. Barry, Domenico Praticò, John A. Lawson, and Garret A. FitzGerald \\ Center for Experimental Therapeutics, University of Pennsylvania, Philadelphia, Pennsylvania 19104
}

\section{Abstract}

Microparticles are released during platelet activation in vitro and have been detected in vivo in syndromes of platelet activation. They have been reported to express both pro- and anticoagulant activities. Nevertheless, their functional significance has remained unresolved.

To address the mechanism(s) of cellular activation by platelet microparticles, we examined their effects on platelets and endothelial cells. Activation of human platelets by diverse stimuli (thrombin, $0.1 \mathrm{U} / \mathrm{ml}$; collagen, $4 \mu \mathrm{g} / \mathrm{ml}$; and the calcium ionophore $\mathrm{A} 23187,1 \mu \mathrm{M}$ ) results in shedding of microparticles. Pretreatment of these particles, but not membrane fractions from resting platelets, with (s)PLA $\mathrm{PL}_{2}$ evokes a dose-dependent increase in platelet aggregation, intracellular $\left[\mathrm{Ca}^{2+}\right]$ movement, and inositol phosphate formation.

These effects localize to the arachidonic acid fraction of the microparticles and are mimicked by arachidonic acid isolated from them. However, platelet activation requires prior metabolism of microparticle arachidonic acid to thromboxane $\mathrm{A}_{2}$. Thus, pretreatment of platelets with the cyclooxygenase $(\mathrm{COX})$ inhibitor, indomethacin $(20 \mu \mathrm{M})$, the thromboxane antagonist SQ29,548 $(1 \mu \mathrm{M})$, or the protein kinase C inhibitor GF109203X $(5 \mu M)$ prevents platelet activation by microparticles. However, platelet microparticles fail to evoke an inositol phosphate response directly, via either of the cloned thromboxane receptor isoforms stably expressed in human embryonic kidney (HEK) 293 cells. Prelabeling platelets with $\left[{ }^{2} \mathrm{H}_{8}\right]$ arachidonate was used to demonstrate platelet metabolism of the microparticle-derived substrate to thromboxane. Platelet microparticles can also induce expression of COX-2 and prostacyclin ( $\mathrm{PGI}_{2}$ ) production, but not expression of COX-1, in human endothelial cells. These effects are prevented by pretreatment with actinomycin $\mathrm{D}(12 \mu \mathrm{M})$ or cycloheximide $(5 \mu \mathrm{g} / \mathrm{ml})$. Expression of COX-2 is again induced by the microparticle arachidonate fraction, which it may then use to synthesize $\mathrm{PGI}_{2}$. Both $\mathrm{PGE}_{2}$ and iloprost, a stable PGI $_{2}$ analog, evoke human umbilical vein endothelial cell COX-2 expression, albeit with kinetics that differ from the response to platelet microparticles. These studies indicate a novel mechanism of transcellular lipid metabolism whereby platelet activation may be amplified or modulated by con-

Address correspondence to Garret A. FitzGerald, Center for Experimental Therapeutics, 901 Stellar-Chance Laboratories, University of Pennsylvania, 422 Curie Blvd., Philadelphia, PA 19104. Phone: 215898-6446; FAX: 215-573-9004; E-mail: garret@spirit.gcrc.upenn.edu

Received for publication 1 October 1996 and accepted in revised form 20 February 1997.

J. Clin. Invest.

(C) The American Society for Clinical Investigation, Inc. 0021-9738/97/05/2118/10 \$2.00

Volume 99, Number 9, May 1997, 2118-2127 centrated delivery of arachidonic acid to adjacent platelets and endothelial cells. (J. Clin. Invest. 1997. 99:2118-2127.) Key words: platelet microparticles $\bullet$ platelets $\bullet$ human umbilical vein endothelial cells $\cdot$ cyclooxygenase- $2 \cdot$ arachidonic acid

\section{Introduction}

A curious feature of eukaryotic cells is that, after activation, they may shed components of their plasma membranes into the extracellular space $(1,2)$. Such fragments may include cytoplasmic elements and are colloquially known as microparticles. Although the formation of such cellular components may involve the translocation of proteins to the cell membrane and the assembly of multimeric complexes (3), the release of microparticles is not associated with cell death, although it may coincide with altered cellular viability (4). Microparticles appear to result from an exocytotic budding process. Thus, microparticles shed by human platelets, which have an average diameter of $\sim 0.1 \mu \mathrm{m}$, contain the cytoplasmic marker factor (F) XIII $\mathrm{A}_{2}$, but not the plasma fibrin-stabilizing F XIII $\mathrm{A}_{2} \mathrm{~B}_{2}$ (5). Recently, the possibility that microparticles might themselves evoke cellular responses in the immediate microenvironment of their formation has been suggested. For example, activation of endothelial cells with thrombin results in vesicle shedding, which, in turn, activates neutrophils and enhances their propensity to adhere to the endothelial cells (6). Similarly, microparticles shed from platelets activated with Staphylococcus aureus $\alpha$-toxin may induce platelet aggregation. Pretreatment of the microparticles with secretory (s) phospholipase $\mathrm{A}_{2}\left(\mathrm{PLA}_{2}\right)^{1}$ was necessary for them to evoke this response (7). Both pro- and anticoagulant proteins have been detected in platelet microparticles (8), and circulating microparticles have been reported in syndromes of platelet activation (9-12).

The present study was designed to explore the mechanism(s) of cellular activation by platelet microparticles. We report that they induce platelet activation by the concentrated transcellular delivery of arachidonic acid and its subsequent metabolism to thromboxane $\mathrm{A}_{2}$. Platelet microparticles may also activate endothelial cells. For example, microvesicular arachidonic acid induces the expression of cyclooxygenase (COX)-2, which, in turn, may process the arachidonate to prostacyclin. Microvesicular shedding may represent a novel mechanism whereby activated platelets and, perhaps, other cells may influence their local environment via transcellular lipid metabolism.

1. Abbreviations used in this paper: AP-1, activator protein-1; COX, cyclooxygenase; HEK, human embryonic kidney; HUVEC, human umbilical vein endothelial cells; IP, inositol phosphate; MP, microparticles; PAF, platelet-activating factor; $\mathrm{PGI}_{2}$, prostacyclin; $\mathrm{PKC}$ (or PKA), protein kinase $\mathrm{C}$ ( or $\mathrm{A}$ ); $\mathrm{PLA}_{2}$, phospholipase $\mathrm{A}_{2}$; PRP, platelet rich plasma; TP, thromboxane receptor; WP, washed platelets. 


\section{Methods}

\section{Reagents}

Calcium ionophore A23187, (s)PLA $\mathrm{PL}_{2}$, indomethacin, $N N$ diisopropyl-ethylamine, pentafluorylbenzyl bromide, EDTA, yohimbine, cycloheximide, actinomycin-D, leupeptin, Nonidet P-40, soybean trypsin inhibitor, and aprotinin were purchased from Sigma Chemical Co. (St. Louis, MO). CV-6209, a platelet activating factor (PAF) receptor antagonist, was obtained from BIOMOL Research Labs. Inc. (Plymouth Meeting, PA). Collagen was purchased from Biodata Corp. (Hatboro, PA). The thromboxane receptor (TP) antagonist SQ29,548, the prostacyclin $\left(\mathrm{PGI}_{2}\right)$ analog Iloprost, $\left[{ }^{2} \mathrm{H}_{8}\right]$ arachidonic acid, $\left[{ }^{2} \mathrm{H}_{4}\right] \mathrm{TxB}_{2},\left[{ }^{2} \mathrm{H}_{4}\right]$ 6-keto $\mathrm{PGF}_{1 \alpha}$, AA, and $\mathrm{PGE}_{2}$ were all purchased from Cayman Chemical Co., Inc. (Ann Arbor, MI). Fura-2/AM, GF109203X (bisindolylmaleimide 1) and H-89 ( $N$-[2-( $p$-bromocinnamylamino) ethyl]-5-isoquinoline-sulfinamide) were purchased from Calbiochem Corp. (La Jolla, CA). The Dowex 1-X8 AG anion exchange resin was purchased from Bio-Rad Laboratories (Hercules, CA). HBSS and Hepes were obtained from Life Technologies, Inc. (Grand Island, NY). The activator protein-1 (AP-1) antibody was a kind gift from Dr. T. Kunicki (Scripps Research Institute, La Jolla, CA). Mouse monoclonal antibodies against COX-1 and COX-2 were kindly provided by Dr. J. Maclouf (INSERM, Unit 348, Paris, France). Rabbit monoclonal antibody against (s) $\mathrm{PLA}_{2}$ was kindly provided by Dr. R. Kramer of Lilly Research Laboratories (Indianapolis, IN). The TP $\beta$ cDNA was a generous gift of Dr. A. Ware of the Beth Israel Hospital (Boston, MA). Human embryonic kidney (HEK) cells were from the American Type Culture Collection (Rockville, MD). Densitometric analysis was performed with Scanner Control Version 1.00 (Molecular Dynamics, Sunnyvale, CA). All solvents were of HPLC grade and obtained from T.J. Baker (Danvers, MA). The reverse phase HPLC column was from Beckman Instruments, Inc. (Fullerton, CA), and the LK60 silica gel 60 A plates (0.25-mm thick) were from Whatman Inc. (Clifton, NJ).

\section{Platelet functional studies}

Isolation of platelets and platelet aggregation. Platelets were harvested as described previously (13). Briefly, blood was collected from healthy volunteers into a plastic syringe containing $3.8 \%$ buffered sodium citrate as anticoagulant (ratio 1:9). The volunteers had not taken any drugs for at least $14 \mathrm{~d}$. Platelet rich plasma (PRP) was prepared by centrifugation at $130 \mathrm{~g}$ for $15 \mathrm{~min}$, and platelet-poor plasma by centrifugation of PRP at $900 \mathrm{~g}$. Washed platelets (WP) were isolated from PRP after centrifugation and resuspended in calcium- and magnesium-free Hepes buffer at $\mathrm{pH}$ 7.4. The platelet number was always adjusted to $3 \times 10^{8}$ platelets $/ \mathrm{ml}$. Platelet aggregation was studied at $37^{\circ} \mathrm{C}$ using WP in a PAP-4 model aggregometer (Biodata Corp.) in siliconized cuvettes with continuous stirring. A number of inhibitors were employed to elucidate the mechanism of platelet aggregation induced by microparticles. These included SQ29,548 $(1 \mu \mathrm{M})$, a specific $\mathrm{TxA}_{2} / \mathrm{PGH}_{2}$ receptor antagonist (14), indomethacin $(20 \mu \mathrm{M})$, a nonspecific COX inhibitor (15), yohimbine (140 nM), an $\alpha_{2}$ adrenergic receptor antagonist (16), CV-6209 (120 nM), a PAF receptor antagonist (17), GF109203X (5 $\mu \mathrm{M})$, a protein kinase C (PKC) inhibitor (18), and H-89 dihydrochloride $(10 \mu \mathrm{M})$, a PKA inhibitor (18). They were all incubated for $1 \mathrm{~min}$ at $37^{\circ} \mathrm{C}$ before addition of platelet agonists: platelet aggregation was followed for $5 \mathrm{~min}$. The supernatant was collected for measurement of $\mathrm{TxB}_{2}$, the stable hydrolysis product of $\mathrm{TxA}_{2}$.

Preparation of platelet microparticles and their identification. Platelet microparticles were isolated after platelet aggregation, as previously described (7). Washed platelets were or were not treated with indomethacin $(20 \mu \mathrm{M})$. The agonists used for platelet activation were thrombin $(0.1 \mathrm{U} / \mathrm{ml})$ and/or collagen $(4 \mu \mathrm{g} / \mathrm{ml})$ or the calcium ionophore A23187 $(1 \mu \mathrm{M})$. Aggregation was followed for $10 \mathrm{~min}$, after which the platelets were sedimented at $1,500 \mathrm{~g}$ for $15 \mathrm{~min}$ and, from the resulting supernatant, microparticles were isolated at $13,000 \mathrm{~g}$ for $45 \mathrm{~min}$. The pellet was resuspended in endotoxin free Hepes, $\mathrm{pH}$
7.4, and then treated with (s)PLA $2(2 \mu \mathrm{g} / \mathrm{ml})$ in the presence of $1 \mathrm{mM}$ $\mathrm{CaCl}_{2}$ at $37^{\circ} \mathrm{C}$ for $1 \mathrm{~h}$. The microparticles were washed twice to remove (s)PLA $\mathrm{P}_{2}$ and resuspended in Hepes buffer at the end of the incubation. The protein content was measured using a microbicinochoninic assay (Pierce Chemical Co., Rockford, IL) with BSA as standard. Samples were analyzed on a flow cytometer (FACScan ${ }^{\circledR}$; Becton Dickinson \& Co., Mountain View, CA) as previously described to characterize the microparticles (19). Briefly, platelet microparticles were incubated with AP-1 (antibody to glycoprotein GP-Ib), for $45 \mathrm{~min}$ at room temperature, and then fixed with $1 \%$ paraformaldehyde. Microparticles were identified by gating on GP1b (FITCAP-1)-positive events and were distinguished by forward scatter size analysis. Each platelet microparticle preparation was assayed for endotoxin contamination by the Limulus amebocyte lysate assay. Final endotoxin contamination was always $<0.02 \mathrm{U} / \mathrm{mg}$ protein. Experiments were also performed with platelet microparticles that were preincubated with polymixin $\mathrm{B}(50 \mu \mathrm{g} / \mathrm{ml})$ for $1 \mathrm{~h}$, before their addition to platelets or to human umbilical vein endothelial cells (HUVEC).

Platelet intracellular calcium and inositol phosphate formation. PRP was incubated with $2 \mu \mathrm{M}$ Fura- $2 / \mathrm{AM}$ at $37^{\circ} \mathrm{C}$ for $45 \mathrm{~min}$, washed to remove the extracellular Fura-2, and resuspended in HBSS, $\mathrm{pH}$ 7.4. Fluorescence measurement was carried out at $37^{\circ} \mathrm{C}$ in a spectrofluorimeter equipped with a magnetic stirrer (LS 50-B, Perkin-Elmer Corp., Beaconsfield, UK). The fluorescence signal was monitored at $510 \mathrm{~nm}$ with excitation wavelengths of 340 and $380 \mathrm{~nm}$. The ratios of maximum and minimum fluorescence were determined by the addition of $250 \mu \mathrm{M}$ digitonin in the presence of $1 \mathrm{mM} \mathrm{CaCl}_{2}$ and in the presence of $10 \mathrm{mM}$ EDTA ( $\mathrm{pH}>8.5)$, respectively, as described previously (13)

PRP was incubated with myo- $\left[2-{ }^{3} \mathrm{H}\right]$ inositol $(50 \mu \mathrm{Ci} / \mathrm{ml})$ at $37^{\circ} \mathrm{C}$ for $3 \mathrm{~h}$, and platelets were harvested as described above. They were then washed in Hepes buffer, $\mathrm{pH}$ 7.4, and resuspended in Hepes containing $20 \mathrm{mM} \mathrm{LiCl}$ for $15 \mathrm{~min}$. These conditions inhibit conversion of inositol phosphates to free inositol. Platelets were incubated with microparticles for $1 \mathrm{~min}$ at $37^{\circ} \mathrm{C}$. Total inositol phosphates were separated on a Dowex 1-X8 AG anion exchange resin (anion form) as previously described (20). Total inositol phosphates were eluted with $4 \mathrm{ml}$ of $2 \mathrm{M}$ formic acid after washing of the column with $40 \mathrm{mM}$ ammonium formate to remove both $\left[{ }^{3} \mathrm{H}\right]$ inositol and $\left[{ }^{3} \mathrm{H}\right]$ glycerophosphorylinositol. $1 \mathrm{ml}$ of the eluant was added to $9 \mathrm{ml}$ of scintillant and the radioactivity was determined using a scintillation counter (Beckman Instruments, Inc., Fullerton, CA).

\section{Lipid analysis}

Lipids were extracted according to a modified version of the method of Bligh and Dyer (21). Lipid separations were performed as previously described (22). Briefly, the lipid extract dissolved in $300 \mu \mathrm{l}$ chloroform was applied to a $100 \mathrm{mg} \mathrm{NH}_{2}$ solid phase extraction cartridge (International Sorbent Technology, Glamorgan, UK) that had been pretreated with $n$-hexane $(2 \mathrm{ml})$. Different mobile phases were used to elute the following fractions: $4 \mathrm{ml}$ of chloroform/isopropanol (2:1) (neutral lipids), $4 \mathrm{ml}$ of $2 \%$ acetic acid in ethyl ether (free fatty acids), and $4 \mathrm{ml}$ of methanol (polar lipids). The neutral lipid fraction was dried and reconstituted in $200 \mu \mathrm{l}$ of hexane and applied to a second pretreated $\mathrm{NH}_{2}$ column. The following fractions were eluted: $4 \mathrm{ml}$ of hexane (cholesteryl esters), $6 \mathrm{ml}$ of $1 \%$ ethyl ether and $10 \%$ dichloromethane in hexane (triglycerides), $6 \mathrm{ml}$ of $5 \%$ ethyl acetate in hexane (cholesterol), $4 \mathrm{ml}$ of $15 \%$ ethyl acetate in hexane (diglycerides), and $4 \mathrm{ml}$ of chloroform/methanol (2:1) (monoglycerides). The free fatty acid fraction recovered from the $\mathrm{NH}_{2}$ column was dried under a stream of nitrogen and redissolved in $20 \mu \mathrm{l}$ of chloroform/methanol $(2: 1, \mathrm{vol} / \mathrm{vol})$ and applied to a silica thin-layer chromatography plate. Plates were developed with the mobile phase $80 \%$ ethyl acetate, $20 \%$ heptane, and $0.1 \%$ acetic acid and the standards made visible with a solution of $\mathrm{CuSO}_{4} / 85 \% \mathrm{H}_{3} \mathrm{PO}_{4}$. The silica plate was divided into 4-cm sections, ethyl acetate extractions with $0.1 \%$ acetic acid were made of each and tested for biological activity as assessed by platelet aggrega- 
tion. The extract with biological activity was dried and resuspended in $50 \mu \mathrm{l}$ of the HPLC mobile phase. A 1050 HPLC (Hewlett-Packard Co., Palo Alto, CA) on line with an HP1050 ultraviolet (UV) detector was used for all HPLC experiments. Reverse phase chromatography used an Ultrasphere ODS $5 \mu \mathrm{m}$ column (Beckman Instruments, Inc.), $4.6 \mathrm{~mm} \times 25 \mathrm{~cm}$. The flow rate was $1 \mathrm{ml} / \mathrm{min}$. A linear gradient mobile phase $18 \%$ acetonitrile $/ \mathrm{H}_{2} \mathrm{O}$ to $100 \%$ acetonitrile in $40 \mathrm{~min}$ was employed (23). Fractions from 5 to $50 \mathrm{~min}$ were collected and dried under a stream of nitrogen. Each fraction was resuspended in 5 $\mu l$ of ethanol and added to a suspension of washed platelets to assess platelet aggregation.

\section{Gas chromatography/mass spectrometry}

All gas chromatography/mass spectrometry studies were performed on a Fisons MD-800 (VG Organic, Manchester, UK) equipped with a split/splitless injector operated in the splitless mode at $260^{\circ} \mathrm{C}$. The interface was maintained at $300^{\circ} \mathrm{C}$, the ion source at $250^{\circ} \mathrm{C}$. The mass spectrometer was operated in the negative ion chemical ionization mode, using ammonia as the reagent gas. Analysis of prostanoids and arachidonic acid was performed as previously described (24). Briefly, a 30-m DB-5 capillary column of $0.25-\mathrm{mm}$ inner diameter with 0.25 $\mu \mathrm{m}$ of coating was used. The temperature program ran from 190 to $320^{\circ} \mathrm{C}$ at $20^{\circ} \mathrm{C} / \mathrm{min}$. The ions monitored were $\mathrm{m} / z$ 614 for $\mathrm{TxB}_{2}$ and 6-keto $\mathrm{PGF}_{1 \alpha}, m / z 618$ for $\left[{ }^{2} \mathrm{H}_{4}\right] \mathrm{TxB}_{2}$ and $\left[{ }^{2} \mathrm{H}_{4}\right]$ 6-keto $\mathrm{PGF}_{1 \alpha}, m / z 621$ for $\left[{ }^{2} \mathrm{H}_{7}\right] 6$-keto $\mathrm{PGF}_{1 \alpha}, \mathrm{m} / z 622$ for $\left[{ }^{2} \mathrm{H}_{8}\right] \mathrm{TxB}_{2}, \mathrm{~m} / z 303$ for $\mathrm{AA}$, and $m / z 311$ for $\left[{ }^{2} \mathrm{H}_{8}\right] \mathrm{AA}$. $\mathrm{TxB}_{2}$ and 6-keto $\mathrm{PGF}_{1 \alpha}$ were both analyzed as the pentafluorylbenzyl ester (PFB)/trimethylsilyl ether derivatives (25), while AA was analyzed as the PFB derivative, as described previously (26).

\section{Cell culture and stimulation}

HUVEC were prepared according to the method of Jaffe et al. (27). Briefly, cells were harvested from human umbilical veins with $1 \mathrm{mg} /$ $\mathrm{ml}$ collagenase A at $450 \mathrm{U} / \mathrm{mg}$ (Boehringer Mannheim, Indianapolis, IN). They were grown to subconfluence in T-25 flasks (Costar Corp., Cambridge, MA) coated with $2 \mathrm{mg} / \mathrm{ml}$ gelatin and maintained in medium 199 (Boehringer Mannheim) containing 10\% heat inactivated human serum, $2 \mathrm{mM}$ glutamine, $100 \mu \mathrm{g} / \mathrm{ml}$ streptomycin, and $100 \mathrm{U}$ penicillin. The medium contained $10 \mu \mathrm{g} / \mathrm{ml}$ heparin and $50 \mu \mathrm{g} / \mathrm{ml}$ endothelial growth supplement. Cells were grown in a humidified atmosphere at $37^{\circ} \mathrm{C}$ in $5 \% \mathrm{CO}_{2}$. HUVEC were characterized by their cobblestone appearance. Passage cells were subcultured into 6-well plates (3-4 $\times 10^{5}$ cells/well) and were allowed to grow under the conditions described above. Heparin and endothelial growth supplement were removed $48 \mathrm{~h}$ before stimulation and replaced with $5 \%$ heat inactivated human serum. Cells were harvested at the second passage at subconfluence and incubated in culture medium containing $0.75 \%$ bovine serum albumin. Platelet microparticles, resuspended in Hepes buffer, were incubated with HUVEC for 2, 6, 12, and $24 \mathrm{~h}$. Supernatants were collected to determine $\mathrm{PGI}_{2}$ production, as reflected by release of its hydrolysis product, 6-keto $\mathrm{PGF}_{1 \alpha}$. SQ29,548 $(2 \mu \mathrm{M})$ and cycloheximide $(5 \mu \mathrm{g} / \mathrm{ml})$ were added to the HUVEC $45 \mathrm{~min}$ before stimulation by microparticles. Actinomycin D $(12 \mu \mathrm{M})$, yohimbine $(140 \mathrm{nM})$, and CV-6209, the PAF receptor antagonist (30 nM), were coincubated with platelet microparticles as described.

\section{Western blot analysis}

Western blot analysis of COX proteins was carried out as previously described (28). Monolayers of HUVEC in 35-mm 6-well plates were lysed in ice-cold buffer (20 mM Tris, pH 8.0, 1 mM EDTA, $1 \%$ Nonidet P-40, $0.25 \%$ SDS, $0.5 \mathrm{mM}$ DTT, $10 \mu \mathrm{g} / \mathrm{ml}$ soybean trypsin inhibitor, $1 \mu \mathrm{g} / \mathrm{ml}$ leupeptin, and $10 \mu \mathrm{g} / \mathrm{ml}$ aprotinin) after incubation with platelet microparticles. The protein content was determined using a microbicinchoninic acid assay (Pierce Chemical Co.) with bovine serum albumin as the standard. $40 \mu \mathrm{g}$ of protein lysate was used for analysis of COX-2 and $20 \mu \mathrm{g}$ for COX-1 analysis by SDS-PAGE. $7 \%$ and $3 \%$ acrylamide was used, respectively, for the separating and stacking gels. Proteins were transferred onto a nitrocellulose membrane with a semidry transfer unit (Hoefer Scientific Instruments,
San Francisco, CA). Blots were then saturated for $2 \mathrm{~h}$ with $5 \%$ fat free milk in Tris buffered saline (Tris- $\mathrm{HCl}, \mathrm{pH} 7.5,250 \mathrm{mM} \mathrm{NaCl}$, $0.1 \%$ Tween 20 ) and incubated with a mouse monoclonal antibody directed against either COX-1 or COX-2 at a concentration of 1/10,000 for $1 \mathrm{~h}$ at room temperature. Both $\mathrm{mAbs}$ are specific for their respective enzymes, no cross-reactivity between the two mAbs has been described $(28,29)$. The $\mathrm{mAb}$ we used for $\mathrm{COX}-1$ does not recognize human COX-2 (29). The mAb against COX-2 recognizes the sequence of the carboxyl-terminal portion of the human COX-2 (C)NASSSRSGLDDINPTVLLK (amino acid sequence 580-598), which is absent from COX-1. Blots were then incubated with sheep antimouse $\operatorname{IgG}_{1}$ conjugated with horseradish peroxidase at 1/2,000 (0.1 $\mathrm{ml} / \mathrm{cm}^{2}$ ) for $1 \mathrm{~h}$ at room temperature. Chemiluminescent substrates were used to reveal positive bands that were visualized after the exposure to Hyperfilm ECL (Amersham Corp., Arlington Heights, IL).

Western blot analysis of (s)PLA $\mathrm{P}_{2}$ in platelet microparticles was also performed. $10,20,40$, and $60 \mu \mathrm{g}$ of microparticle protein was used for analysis of (s)PLA $\mathrm{PL}_{2}$. The separating and stacking gels employed 15 and $3 \%$ acrylamide, respectively. Proteins were transferred onto a nitrocellulose membrane with a semidry transfer unit. Blots were then saturated for $2 \mathrm{~h}$ with $5 \%$ fat free milk in Tris buffered saline (Tris- $\mathrm{HCl}, \mathrm{pH} 7.5,250 \mathrm{mM} \mathrm{NaCl}, 0.1 \%$ Tween 20) and incubated with a rabbit monoclonal antibody directed against (s)PLA $\mathrm{PL}_{2}$ at a concentration of $1 / 10,000$ for $1 \mathrm{~h}$ at room temperature. Blots were then incubated with rabbit anti-mouse $\mathrm{IgG}_{1}$ conjugated with horseradish peroxidase at $1 / 5,000\left(0.1 \mathrm{ml} / \mathrm{cm}^{2}\right)$ for $1 \mathrm{~h}$ at room temperature. Chemiluminescent substrates were used to reveal positive bands that were visualized after exposure to Hyperfilm ECL.

\section{Cell culture and transfections}

HEK 293 cells were routinely grown in Dulbecco's modified Eagle's medium. Transfections were carried out as previously described (30). The cDNAs encoding the placental (TP $\alpha$; reference 31$)$ or endothelial (TP $\beta$; reference 32) human thromboxane receptor isoforms were subcloned into the EcoRI-EcoRI or the EcoRI-XbaI sites, respectively, of the G418-resistant mammalian expression vector pcDNA111 (Invitrogen Corp., San Diego, CA). Receptor expression was verified in several cell lines by Northern blot analysis, using the respective cDNAs as probes.

\section{Inositol phosphate formation}

The HEK-transfected cells in the presence of DMEM inositol free medium were labeled with $m y o-\left[2-{ }^{3} \mathrm{H}\right]$ inositol $(1 \mu \mathrm{Ci} / \mathrm{ml})$ at $37^{\circ} \mathrm{C}$ for $24 \mathrm{~h}$. The medium was then removed and replaced with inositol free DMEM containing $20 \mathrm{mM} \mathrm{LiCl}$ for $15 \mathrm{~min}$ at $37^{\circ} \mathrm{C}$. These conditions inhibit conversion of inositol phosphates to free inositol. The HEK cells were then incubated with platelet microparticles for $10 \mathrm{~min}$ at $37^{\circ} \mathrm{C}$. Total inositol phosphates were separated on a Dowex 1-X8 AG anion exchange resin (anion form) as previously described (20). The measurement of total inositol phosphates was carried out as outlined above for platelets.

\section{Statistical analysis}

Results are expressed as mean \pm SEM. Statistical comparisons were made by using analysis of variance with subsequent application of Student's $t$ test as appropriate.

\section{Results}

Effects of microparticles on human platelets. Washed human platelets stimulated with either A23187 or thrombin in the presence or absence of indomethacin $(20 \mu \mathrm{M})$ resulted in microparticle formation. We confirmed microparticle formation by FACS $^{\circledR}$ analysis of AP-1 binding as previously described (19). Thus, platelet microparticle formation is not cyclooxygenase dependent. Microparticles may evoke biological responses irrespective of the cyclooxygenase activity of their 

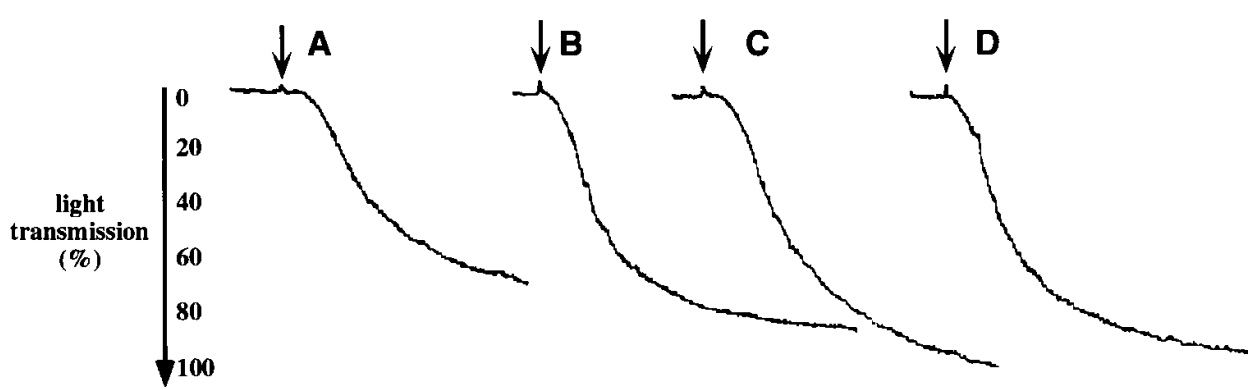

Figure 1. Platelet aggregation induced by microparticles. $(A)$ A23187-generated platelet microparticles from aspirinated platelets induce platelet aggregation. $(B)$ A23187-generated platelet microparticles from nonaspirinated platelets induce platelet aggregation. (C) A23187 $(1 \mu \mathrm{M})$ induced aggregation of nonaspirinated platelets. (D) Thrombin $(0.1 \mathrm{U} / \mathrm{ml})$ induced aggregation of nonaspirinated platelets. The traces are representative of four experiments. The arrows indicate the addition of microparticles or the platelet agonist to washed platelets. platelet source (Fig. 1). Thus, incubation of washed human platelets with microparticles $(5-40 \mu \mathrm{g}$ protein $/ \mathrm{ml}$ ) results in a dose-dependent increase in platelet aggregation and $\mathrm{TxB}_{2}$ formation (Fig. 2). The magnitude of the response evoked by concentrations of microparticles typically shed by activated platelets in vitro $\left(260 \mu \mathrm{g}\right.$ microparticles protein $/ 3 \times 10^{8}$ platelets) corresponds to that evoked by chemical (A23187) and biological (thrombin) agonists. Irreversible aggregation is only observed when the microparticles are first treated with (s)PLA $(2 \mu \mathrm{g} / \mathrm{ml})$. (s) $\mathrm{PLA}_{2}$ alone does not cause platelet aggregation. We excluded the presence of endogenous (s)PLA $\mathrm{P}_{2}$ in the microparticle preparation by Western blot analysis (Fig. 3). Addition of the thromboxane receptor antagonist SQ29,548 (1 $\mu \mathrm{M})$ results in a $79.8 \pm 9.8 \%(n=6)$ reduction in microparticleinduced platelet aggregation (Fig. 4). Similarly, the COX inhibitor, indomethacin $(20 \mu \mathrm{M})$, results in an $81 \pm 6.8 \%$ reduction and the PKC inhibitor, GF109203X (5 $\mu \mathrm{M})$, results in a $66.6 \pm 7.4 \%(n=6)$ reduction in platelet aggregation. A corresponding decrease in $\mathrm{TxB}_{2}$ production is also observed (data not shown). The $\alpha_{2}$-adrenergic receptor antagonist, yohimbine $(140 \mathrm{nM})$, the PAF antagonist CV-6209 $(120 \mu \mathrm{M})$, and the PKA antagonist, H-89 dihydrochloride $(10 \mu \mathrm{M})$, all fail to pre-

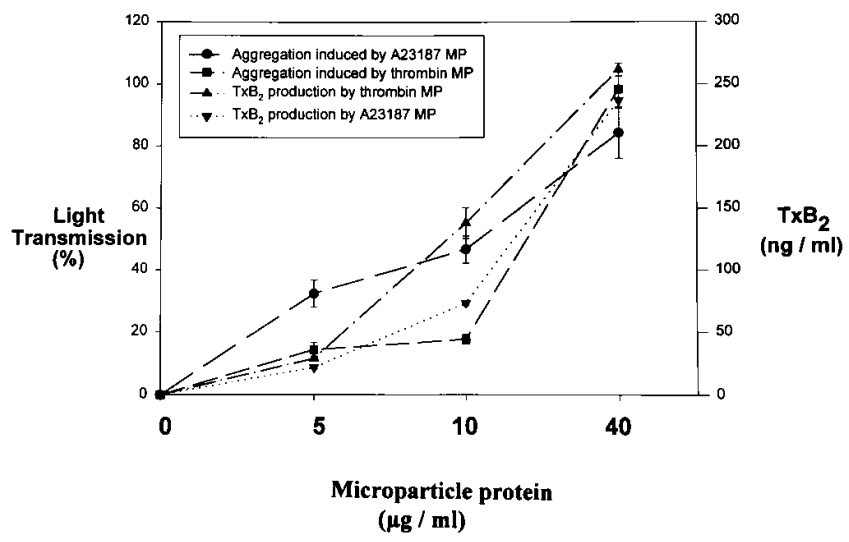

Figure 2. Dose-dependent increase in platelet aggregation and platelet $\mathrm{TxB}_{2}$ production. The aggregation trace was followed for $5 \mathrm{~min}$ and expressed as the percentage increase in light transmission. The platelet supernatant was collected after $5 \mathrm{~min}$ for $\mathrm{TxB}_{2}$ measurement. Each point represents the mean \pm SEM of six experiments. vent microparticle-induced platelet aggregation (data not shown). Microparticles cause a dose-dependent increase in intracellular calcium when added to human platelets loaded with Fura-2/AM (Fig. 5). To investigate the origin of this calcium movement, Fura-2-loaded platelets were pretreated with 1 $\mathrm{mM} \mathrm{CaCl} 2$ to increase a potential influx of extracellular calcium. Similarly, they were pretreated with 2 mM EGTA to chelate extracellular calcium. No change in the microparticleevoked calcium signal is observed upon treatment with either reagent. This implies that platelet microparticles induce mobilization of calcium from intracellular stores. When washed human platelets were incubated with microparticles, we observed a dose-dependent increase in platelet inositol phosphates (IPs) (Table I). Similarly, U46619 caused a marked increase in platelet IP formation.

Platelet microparticles and thromboxane receptor activation. Since SQ29,548 causes a significant reduction in platelet aggregation induced by microparticles, we addressed the possibility that they might activate directly either of the two cloned thromboxane receptor isoforms. Formation of IPs was measured in HEK 293 cells, which stably expressed the recombinant TP $\alpha$ and TP $\beta$ isoforms. Platelet microparticles, in concentrations up to $40 \mu \mathrm{g} / \mathrm{ml}$, fail to increase total IPs in either case. The $\mathrm{PGH}_{2} / \mathrm{TxA}_{2}$ analog, U46619, by contrast, markedly increases IP formation in cells expressing either isoform (Fig. 6).

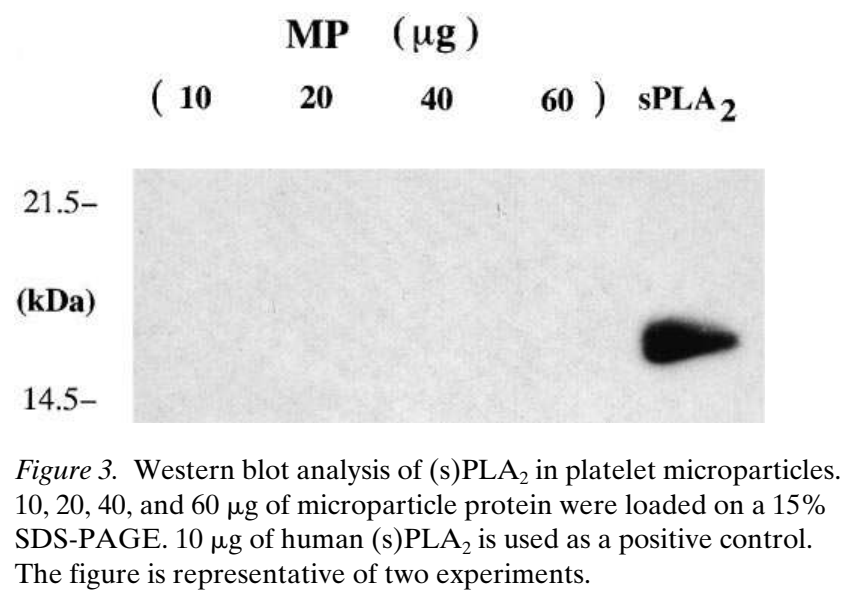

Transcellular Activation of Platelets and Endothelial Cells 




Figure 4. Inhibition of platelet aggregation. WP were incubated with the thromboxane antagonist SQ29,548 $(S Q)(1 \mu \mathrm{M})$, the COX inhibitor indomethacin (Indo) $(20 \mu \mathrm{M})$, or the PKC inhibitor GF109203X $(G F)(5 \mu \mathrm{M})$, and then stimulated with microparticles (MP) $(20 \mu \mathrm{g})$. Platelet aggregation was followed for $5 \mathrm{~min}$ and expressed as the percentage increase in light transmission. Each point represents the mean \pm SEM of eight experiments.

Identification of the biological mediator present in platelet microparticles. Neither the neutral nor the polar lipid fractions extracted from microparticles and recovered from the $\mathrm{NH}_{2}$ column express biological activity when added to washed platelets. However, the free fatty acid fraction dose-dependently increases platelet aggregation (data not shown). To identify the component of this fraction that was responsible for the activity, we subjected it first to TLC. The band that evokes platelet aggregation has the same $R_{\mathrm{f}}$ value as an arachidonic acid standard. Next, the fraction was subjected to purification by reverse phase HPLC. Only one fraction results in a dosedependent increase in platelet aggregation. This had a retention time of $39.9 \mathrm{~min}$, which coincides with the retention time for the arachidonic acid standard (Fig. 7). Finally, the HPLC active fraction was analyzed as the pentafluorobenzyl ester. Mass spectral analysis employed electron capture, negative ion chemical ionization with selected ion monitoring at $\mathrm{m} / \mathrm{z} 303$



Figure 5. Platelet intracellular calcium response by MP. Human platelets were loaded with Fura-2/AM and stimulated with MP $5 \mu \mathrm{g}$ (trace 1 ), $10 \mu \mathrm{g}$ (trace 2), and $20 \mu \mathrm{g}$ (trace 3 ). The data shown are representative of three experiments.
Table I. Inositol Phosphate Formation by Human Platelets Stimulated with Microparticles and U46619

\begin{tabular}{lc}
\hline Microparticles $(\mu \mathrm{g} / \mathrm{ml})$ & Percent increase in IPs \\
\hline 5 & $45.8 \pm 10.2$ \\
10 & $65.3 \pm 6.1$ \\
20 & $92.2 \pm 1.6$ \\
40 & $111.6 \pm 6.1$ \\
$\mathrm{U} 46619(1 \mu \mathrm{M})$ & $121.3 \pm 4.8$
\end{tabular}

Dose-dependent stimulation of $\left[{ }^{3} \mathrm{H}\right]$ inositol phosphate formation by platelet microparticles. Platelets were prelabeled with myo-[2- $\left.{ }^{3} \mathrm{H}\right]$ inositol $(50 \mu \mathrm{Ci} / \mathrm{ml})$, and experiments were carried out in the presence of $\mathrm{LiCl}$ (20 mM). The level of total inositol phosphate formation was measured by Dowex-1 anion exchange chromatography as described in Methods. Each point represents the mean \pm SEM of three separate experiments.

and $m / z, 311$, for the deuterated internal standard (Fig. 8). The intense fragment ions found at $\mathrm{m} / z .311$ and $\mathrm{m} / z 303$ arise from the loss of the pentafluorobenzyl radical, leaving the carboxylate anion in high abundance (Fig. 9, $A$ and $B$, respectively).

Arachidonic acid distribution and its transcellular metabolism. To investigate the distribution of arachidonic acid between platelets and microparticles, PRP was incubated with 1 $\mu \mathrm{Ci} / \mathrm{ml}\left[{ }^{3} \mathrm{H}\right] \mathrm{AA}$ for $1 \mathrm{~h}$ at $37^{\circ} \mathrm{C}$. Platelets were harvested and washed to remove the free arachidonate. Microparticles were formed by aggregating platelets with A23187 $(1 \mu \mathrm{M})$ in the presence of $20 \mu \mathrm{M}$ indomethacin. The percentage of radioactivity associated with the platelet pellet was $40 \pm 1.5 \%$, while the amount released in microparticles was $32 \pm 2.1 \%$ (Table II). The amount found in the supernatant was $29.7 \pm 1.8 \%$. In two experiments, treatment of the platelet microparticles with (s)PLA $\mathrm{P}_{2}$ increased microparticle-associated radioactivity by 23 and $31 \%$. Similar results were obtained when washed platelets were stimulated with thrombin (data not shown). Microparticles generated from WP loaded with $2 \mu \mathrm{M}\left[{ }^{2} \mathrm{H}_{8}\right] \mathrm{AA}$ were

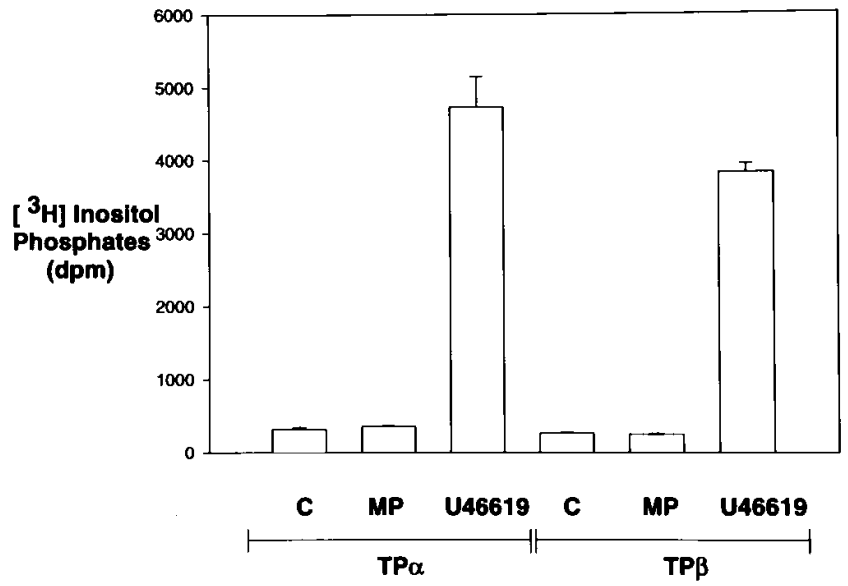

Figure 6. Total inositol phosphate formation by HEK 293 cells stimulated with platelet microparticles or the $\mathrm{PGH}_{2} / \mathrm{TxA}_{2}$ analog, U46619. HEK 293 cells transfected with the placental $(T P \alpha)$ or the endothelial $(T P \beta)$ receptors were prelabeled with $m y o-\left[2-{ }^{3} \mathrm{H}\right]$ inositol $(1 \mu \mathrm{Ci} / \mathrm{ml})$ and stimulated with MP $(40 \mu \mathrm{g} / \mathrm{ml})$ or U46619 $(1 \mu \mathrm{M})$. Controls $(C)$ are unstimulated HEK 293 cells. Each point represents the mean \pm SEM of four experiments. 


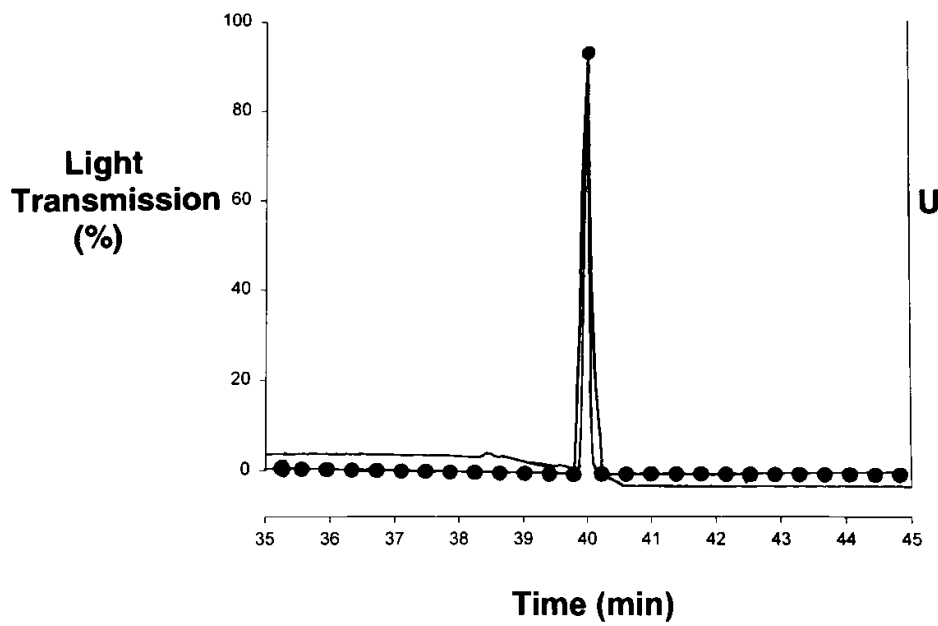

UV Abs. / 190nm

Figure 7. Coelution of the biological mediator isolated from microparticles $(\bullet)$ with the UV absorption profile of authentic arachidonic acid (-). Reverse phase HPLC of the underivatized compound was run with a gradient mobile phase: $18 \%$ acetonitrile/ $82 \%$ water to $100 \%$ acetonitrile in $40 \mathrm{~min}$. Fractions were collected each minute and monitored at $190 \mathrm{~nm}$. added to freshly prepared platelets to address the possibility that they might donate arachidonate for transcellular metabolism. $\left[{ }^{2} \mathrm{H}_{8}\right] \mathrm{TxB}_{2}$ is undetectable before platelet activation, but rises to $423.3 \pm 43.3 \mathrm{pg} / \mathrm{ml}$ in the supernatant after platelet aggregation for $5 \mathrm{~min}$ with $10 \mu \mathrm{g} / \mathrm{ml}$ protein. This result implies that intact platelets possess the capacity to use arachidonate from platelet microparticles to generate $\mathrm{TxA}_{2}$, a platelet ago-

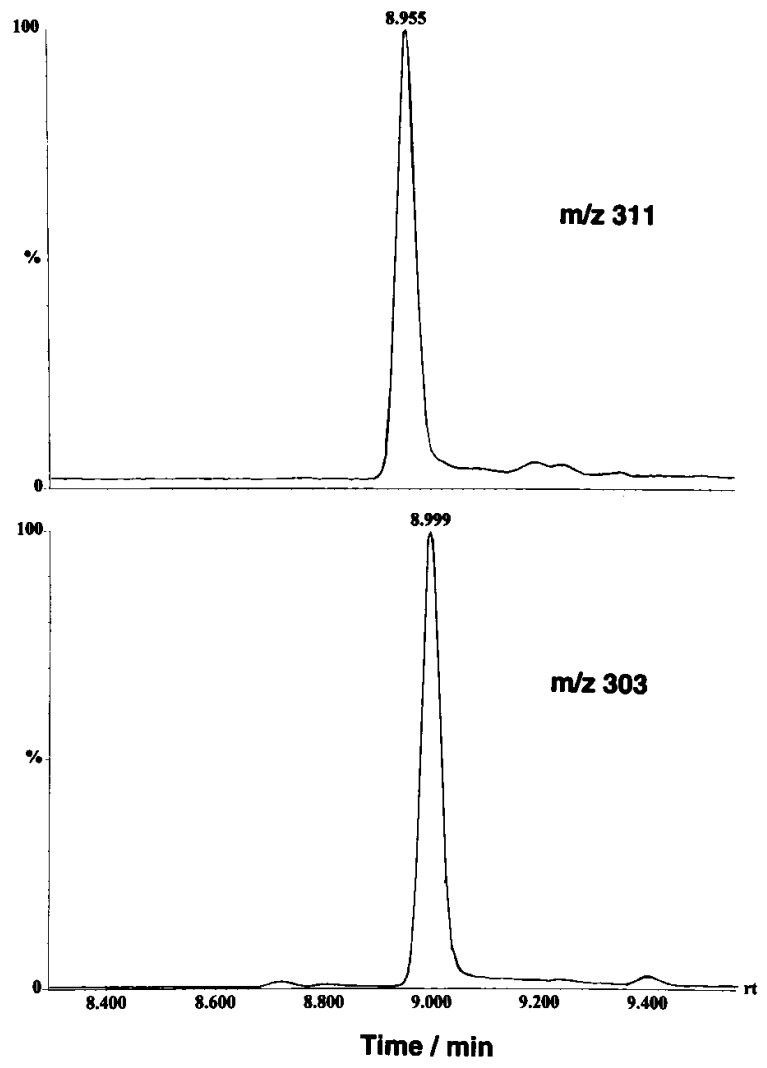

Figure 8. Selected ion monitoring of the active fraction isolated from platelet microparticles. $\left[{ }^{2} \mathrm{H}_{8}\right] \mathrm{AA}(5 \mathrm{ng})$ was added to the HPLC active fraction and analyzed as the pentafluorobenzyl ester derivative. The upper trace shows a peak at $m / z 311$ corresponding to $\left[{ }^{2} \mathrm{H}_{8}\right] \mathrm{AA}-$ labeled internal standard. The lower trace shows a peak at $\mathrm{m} / z 303$ corresponding to unlabeled arachidonic acid. nist and vasoconstrictor. We also investigated whether HUVEC might use the AA present in platelet microparticles. Similarly, HUVEC enzymatically metabolizes $\left[{ }^{2} \mathrm{H}_{8}\right] \mathrm{AA}$, since the stable hydrolysis product of prostacyclin $\left(\mathrm{PGI}_{2}\right),\left[{ }^{2} \mathrm{H}_{7}\right]$ 6-keto $\mathrm{PGF}_{1 \alpha}$, was detected in the supernatant after exposure to platelet microparticles. The concentration of $\left[{ }^{2} \mathrm{H}_{7}\right] 6$-keto $\mathrm{PGF}_{1 \alpha}$ rises time dependently from an undetectable level at time $0 \mathrm{~h}$ to $62.7 \pm 2.5$ $\mathrm{pg} / \mathrm{ml}$ at $2 \mathrm{~h}$, and $266.7 \pm 20.8,226.7 \pm 15.3$, and $69.7 \pm 9.4 \mathrm{pg} / \mathrm{ml}$ at 6,12 , and $24 \mathrm{~h}$, respectively.

Induction of cyclooxygenase activity in HUVEC by platelet microparticles. HUVEC were incubated with platelet microparticles $(6 \mu \mathrm{g} / \mathrm{ml})$ for various time periods $(2,6,12$, and $24 \mathrm{~h})$ to address the mechanism by which $\mathrm{PGI}_{2}$ formation might be induced. Western blot analysis indicates that platelet microparticles do not induce the expression of COX-1 (data not shown). COX-2 expression, however, increases in response to platelet microparticles. Thus, the protein is apparent at very low levels in controls, perhaps reflecting some degree of cellular activation as previously described (28). However, expression rose significantly from control levels $(136.67 \pm 26.03$ densitometric units), reaching a maximum at $6 \mathrm{~h}(1,293.67 \pm 84.48$ densitometric units, $P=0.0001$ ) (Fig. $10 A$ ). No difference in COX-2 expression was observed when microparticles were first treated with polymixin B $(50 \mu \mathrm{g} / \mathrm{ml})$ for $1 \mathrm{~h}$ before addition to HUVEC to rule out any contamination by LPS (data not shown). Expression of COX-2 protein is associated with $\mathrm{PGI}_{2}$ synthesis, as measured by 6 -keto $\mathrm{PGF}_{1 \alpha}$ in the supernatant (see Fig. 12). Indomethacin $(20 \mu \mathrm{M})$ was always added to the medium before the addition of platelet microparticles to

Table II. Arachidonic Acid Released from Human Platelets Activated with A23187

\begin{tabular}{lc}
\hline \multicolumn{1}{c}{ Fractions } & Percent $\left[{ }^{3} \mathrm{H}\right]$ arachidonic acid \\
\hline Microparticles & $32.0 \pm 2.1$ \\
Supernatant & $29.7 \pm 1.8$ \\
Platelets & $40.0 \pm 1.5$ \\
\hline
\end{tabular}

Platelets $\left(3 \times 10^{8}\right)$ were stimulated with A23187 $(1 \mu \mathrm{M})$ for $10 \mathrm{~min}$ at $37^{\circ} \mathrm{C}$. Microparticles, a pellet obtained after $100,000 \mathrm{~g}$ centrifugation; supernatant, obtained at 100,000 $\mathrm{g}$ centrifugation. Each point represents the mean \pm SEM of four separate experiments. 

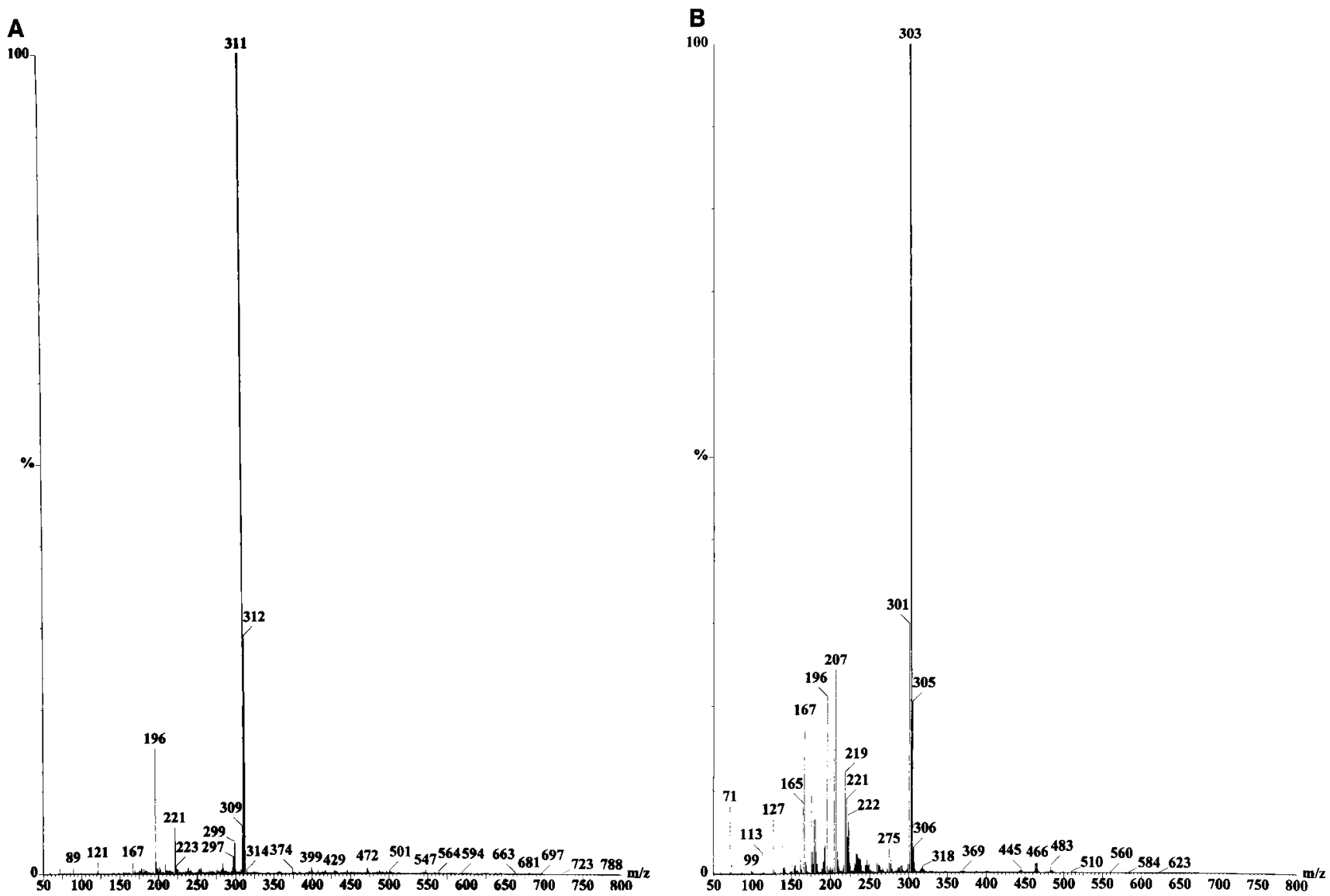

Figure 9. Electron capture negative ion chemical ionization mass spectrum. $A$ shows a spectrum of $\left[{ }^{2} \mathrm{H}_{8}\right]$ AA derivatized as the pentaflourylbenzyl ester derivative, while $B$ shows a spectrum of the active principle isolated from the platelet microparticles.

inhibit constitutive activity of $\mathrm{COX}(\mathrm{s})$. Actinomycin D (12 $\mu \mathrm{M})$ and cycloheximide $(5 \mu \mathrm{g} / \mathrm{ml})$ inhibited COX-2 expression and 6-keto $\mathrm{PGF}_{1 \alpha}$ production induced by platelet microparticles $(173.97 \pm 5.96$ and $161.09 \pm 11.06$ densitometric units, respectively, $6 \mathrm{~h}$ after stimulation) (Fig. 10; Table III). By contrast, SQ29,548 $(2 \mu \mathrm{M})$, yohimbine $(140 \mathrm{nM})$, and CV-6209 (30 $\mathrm{nM})$ all failed $(P>0.05)$ to reduce either COX-2 expression $(1,058.53 \pm 104.87,1,097.62 \pm 108.97$, and $917 \pm 116.93$ densitometric units, respectively, $6 \mathrm{~h}$ after stimulation), or 6-keto $\mathrm{PGF}_{1 \alpha}$ production from the maximal values stimulated by platelet microparticles (Fig. 10; Table III). To investigate further the contribution of COX-2 to $\mathrm{PGI}_{2}$ production, we used L-745,337, a specific inhibitor of COX-2 (33). L-745,337 (10 $\mu \mathrm{M})$ markedly reduced the ability of A23187-generated platelet microparticles to augment HUVEC 6-keto $\mathrm{PGF}_{1 \alpha}$ production. This was reduced by $81.2 \% \pm 5.5$ at $2 \mathrm{~h}$, by $74.9 \% \pm 4.4$ at $6 \mathrm{~h}$, by $75.6 \% \pm 3.5$ at $12 \mathrm{~h}$, and by $70.3 \% \pm 3.2$ at $24 \mathrm{~h}$. Similar results were obtained when L-745,337 was added to HUVEC in the presence of thrombin-generated microparticles (data not shown).

Arachidonic acid induction of $C O X-2$ expression. Since we observed that the AA fraction was the mediator of microparticle-induced activation of washed platelets, we decided to investigate its role in the endothelial response. Arachidonic acid was isolated from both A23187 and thrombin-generated platelet microparticles, as previously described, and added to HUVEC at various time points. Indomethacin $(20 \mu \mathrm{M})$ was present in the medium before the addition of microparticle arachidonate to prevent AA metabolism. The same time course of COX-2 expression was observed with arachidonic acid as for intact platelet microparticles. Again, the protein is

Table III. Effect of SQ29,548, Yohimbine, CV-6209, Actinomycin D, and Cycloheximide on 6-keto $P G F_{1 \alpha}$ Production by HUVEC When Stimulated with Platelet Microparticles $(6 \mu \mathrm{g} / \mathrm{ml})$

\begin{tabular}{lrr}
\hline & \multicolumn{2}{c}{ 6-Keto PGF $_{1 \alpha}(\mathrm{ng} / \mathrm{ml})$} \\
\cline { 2 - 3 } Preincubation conditions & \multicolumn{1}{c}{ A23187 } & \multicolumn{1}{c}{ Thrombin } \\
\hline Microparticles alone & $16.87 \pm 1.35$ & $13.95 \pm 1.29$ \\
MP + SQ29,548 & $14.35 \pm 3.15$ & $10.56 \pm 2.51$ \\
MP + yohimbine & $16.21 \pm 3.24$ & $13.25 \pm 2.39$ \\
MP + CV-6209 & $15.95 \pm 2.42$ & $12.89 \pm 1.43$ \\
MP + actinomycin D & $1.37 \pm 0.10$ & $1.84 \pm 0.50$ \\
MP + cycloheximide & $1.97 \pm 0.21$ & $1.73 \pm 0.27$
\end{tabular}

SQ29,548 $(2 \mu \mathrm{M})$, yohimbine $(140 \mathrm{nM})$, and CV-6209 $(30 \mu \mathrm{M})$ were incubated with HUVEC for 45 min before addition of platelet microparticles. Actinomycin D $(12 \mu \mathrm{M})$ and cycloheximide $(5 \mu \mathrm{g} / \mathrm{ml})$ were coincubated with platelet microparticles. 6-Keto $\mathrm{PGF}_{1 \alpha}$ production was measured in the supernatant by gas chromatography/mass spectrometry after a 6-h incubation period. Each point represents the mean \pm SEM of six separate experiments. 
A MP ( $6 u \mathrm{~g} / \mathrm{ml})$

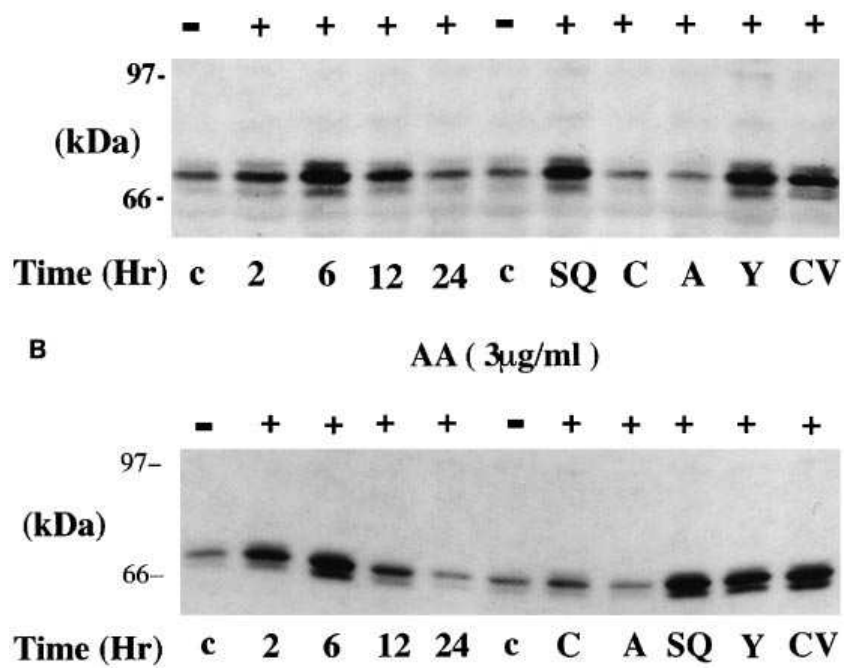

Figure 10. Western blot analysis of COX-2 protein expression in HUVEC treated with platelet MP $(6 \mu \mathrm{g} / \mathrm{ml})(A)$ and AA isolated from MP $(3 \mu \mathrm{g} / \mathrm{ml})(B)$. HUVEC $\left(3-4 \times 10^{5}\right.$ cells/well $)$ were incubated with medium only (control, $c$ ); with MP alone for 2, 6, 12, or $24 \mathrm{~h}$; with MP + either SQ29,548 (SQ), cycloheximide $(C)$, actinomycin D $(A)$, yohimbine $(Y)$, or CV-6209 (CV) for $6 \mathrm{~h}$. The lower blot shows HUVEC incubated with medium only (control, $c$ ), with arachidonate isolated from platelet microparticles for $2,6,12$, or $24 \mathrm{~h}$, with AA + either SQ29,528 $(S Q)$, cycloheximide $(C)$, actinomycin D $(A)$, yohimibine $(Y)$, or CV-6209 $(C V)$ for $6 \mathrm{~h}$. The figure is representative of five experiments.

apparent at very low levels in controls $(139 \pm 7.21$ densitometric units), while maximum expression of COX-2 induced by AA is observed at $6 \mathrm{~h}(1,142.33 \pm 41.01$ densitometric units, $P=0.00001$ ) (Fig. 10, B). Consistent with the data obtained with microparticles, SQ29,548, yohimbine, and CV-6209 all fail $(P>0.05)$ to suppress the expression of COX-2 induced by arachidonic acid $(1,077.62 \pm 109.33,1,033.79 \pm 62.91$, and $1,033 \pm 39.80$ densitometric units, respectively, at $6 \mathrm{~h}$ ). Actinomycin D and cycloheximide, by contrast, both reduce expression of the COX-2 protein $(116.50 \pm 9.28$ and $244.09 \pm 16.85$ densitometric units, respectively, at the same time point) (Fig. $10, B)$. To investigate further the likelihood that microparticledependent induction of COX-2 was indeed mediated by AA itself and not one of its metabolites, we coincubated HUVEC with a $\mathrm{PGI}_{2}$ analogue, Iloprost $(100 \mathrm{nM})$, and $\mathrm{PGE}_{2}(10 \mu \mathrm{M})$ for 2, 6, 12, and $24 \mathrm{~h}$ as for AA (Fig. 11). Both Iloprost and $\mathrm{PGE}_{2}$, when added to HUVEC, induce COX-2 expression. However, the kinetics of protein expression are different from those evoked by microparticle arachidonate. Maximum induction of COX-2 expression by Iloprost occurs at $2 \mathrm{~h}$, while $\mathrm{PGE}_{2}$ induces COX-2 over a 24-h period. This contrasts with the results for $\mathrm{AA}$, or intact microparticles where maximum COX-2 expression and 6-keto $\mathrm{PGF}_{1 \alpha}$ production (Fig. 12) occurs at $6 \mathrm{~h}$ and decreases to near basal levels at $24 \mathrm{~h}$.

\section{Discussion}

Microparticles shed by aggregating platelets may, in turn, cause platelet activation. The active principle in the micropar-

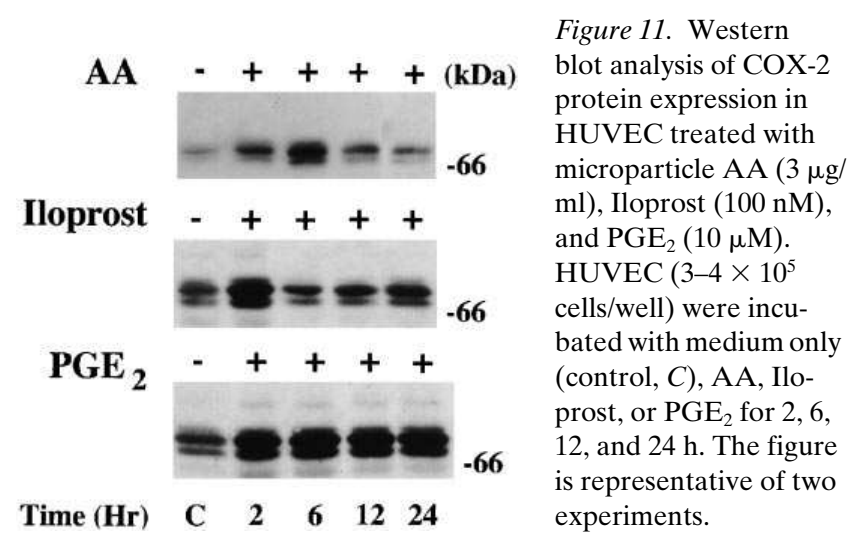

ticles is identified as arachidonic acid. Rather than stimulate platelets directly, we demonstrate that the arachidonic acid must first be subjected to metabolism to thromboxane $\mathrm{A}_{2}$. Thus, pretreatment of platelets with the cyclooxygenase inhibitor, indomethacin, or the thromboxane antagonist SQ29,548 inhibits the ability of the microparticles to induce platelet aggregation. These data are consistent with the observation that the microparticles fail to evoke cellular activation directly via either of the cloned thromboxane receptor isoforms. They are also consistent with the dose-dependent increase in platelet calcium concentration, inositol phosphates, and thromboxane formation evoked by the microparticles and by inhibition of microparticle-induced platelet aggregation by an inhibitor of protein kinase $\mathrm{C}$. Thromboxane receptor activation by ligands results in an increased phospholipase $\mathrm{C}$ activity with a consequent increase in intracellular calcium and activation of protein kinase C (34). Prelabeling of esterified platelet arachidonic acid with stable isotopes indicates that the arachidonate in the microparticles may serve as a direct source of thromboxane formation in microparticle-activated platelets.

Our results in platelets are consistent with a previous report that microparticles may evoke biological responses only

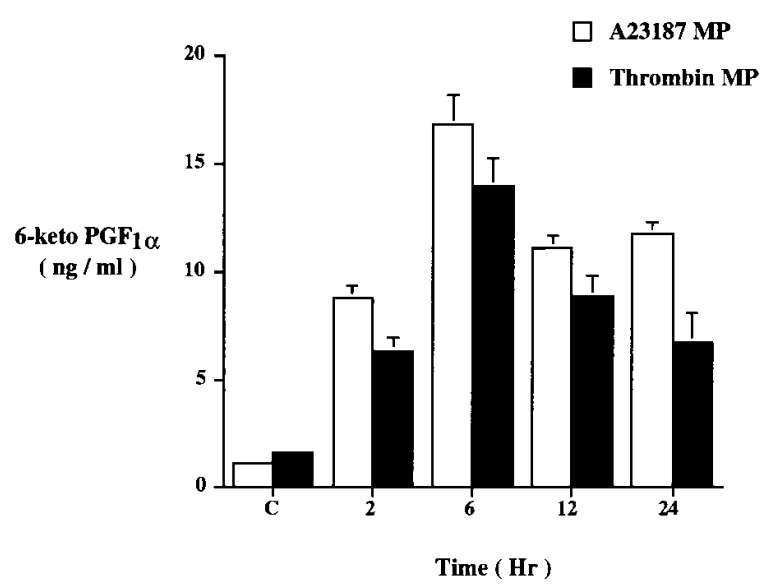

Figure 12. Time course of 6-keto $\mathrm{PGF}_{1 \alpha}$ production in HUVEC stimulated with platelet MP $(6 \mu \mathrm{g} / \mathrm{ml})$. The supernatant was assayed for 6-keto $\mathrm{PGF}_{1 \alpha}$ by gas chromatography/mass spectrometry at the indicated times after exposure to MP formed by platelets activated either by the calcium ionophore A23187 ( $\square$ ) or thrombin ( $\mathbf{\square})$. Values are reported as mean \pm SEM from five experiments. 
after treatment with (s)PLA 2 and sphingomyelinase (7). Experiments with radiolabeled arachidonic acid suggest that addition of (s)PLA $\mathrm{PL}_{2}$ to the microparticles enhanced the availability of the lipid for transcellular exchange. Microparticles alone, without such pretreatment, or (s)PLA $\mathrm{PA}_{2}$ alone failed to induce platelet aggregation. We used $2 \mu \mathrm{g} / \mathrm{ml}$ of (s)PLA $\mathrm{PL}_{2}$ in our system. This is comparable to the levels of (s)PLA $\mathrm{PL}_{2}$ that circulate in the plasma of patients with systemic inflammation $(35,36)$. Cellular activation may result in translocation of (s)PLA $\mathrm{PL}_{2}$ to the membrane. (s)PLA $\mathrm{PL}_{2}$ is shed by activated platelets, but tends to remain cell associated in endothelial cells (37). Either source could facilitate release of microparticle arachidonate in vivo.

Platelet-derived microparticles may also influence endothelial function. We have demonstrated that microparticles induce de novo expression of COX-2, but not COX-1, in indomethacin-pretreated endothelial cells. Again, arachidonic acid appears to be a sufficient active principle. Results with pharmacological inhibitors suggest that this is not mediated via activation of thromboxane, platelet activating factor, or alpha adrenergic receptors. Although the mechanism by which arachidonic acid induces COX expression remains to be elucidated, experiments with stable isotope-labeled substrate indicate that the arachidonate in the microparticles may serve as a substrate for the induced enzyme, contributing to augmented $\mathrm{PGI}_{2}$ formation. Interestingly, both $\mathrm{PGE}_{2}$ and $\mathrm{PGI}_{2}$ (iloprost), products of COX metabolism of arachidonate in endothelial cells, may upregulate COX-2 in HUVEC. However, the time course of induction of protein expression suggests that they do not account for the predominant response to microparticles in this experiment. However, it is possible that such metabolites might augment the response to microparticle arachidonate in vivo. Direct effects of arachidonic acid on cellular function have been described previously. These include modulation of ion channel function, lipidation of enzymes and signaling proteins, and growth factors $(38,39)$. The role of arachidonic acid and related lipids in gene induction has received particular attention $(40,41)$.

Arachidonic metabolites have previously been shown to exhibit the potential for transcellular metabolism. Thus, Marcus and colleagues have previously demonstrated that plateletderived endoperoxides may be used by endothelial cells as a substrate for $\mathrm{PGI}_{2}$ synthesis (42); such a concept underlay the development of thromboxane synthase inhibitors. Similarly, platelet lipoxygenase products may undergo further processing by neutrophils or erythrocytes to give rise to novel hydroxy eicosatetraenoic acids of altered biological function (43). Neutrophil-derived lipoxygenase products may be further metabolized by erythrocytes and platelets or endothelial cells (44). Our studies extend these observations. Firstly, they demonstrate that microparticles may serve as a delivery system for bioactive lipids between cells. Although arachidonic acid accounts for the biological activities that we have studied, this concept may extend to other lipids. Thus, Lorant et al. have identified PAF-like lipids in the microparticles shed by activated endothelial cells that facilitate cellular adhesive interactions (45). Secondly, they demonstrate that arachidonic acid itself, rather than one of its downstream metabolites, may be subject to transcellular transfer. Finally, they illustrate a mechanism by which the consequences of platelet activation may be amplified or modulated. It is likely that such a process may extend to other cells in the milieu of a forming thrombus. These experiments were conducted in vitro, in the absence of such forces as shear and flow. However, it is likely that shear will enhance the release of microparticles (46). The existence of flow vortices in proximity to the evolving thrombus may enhance the likelihood of interaction with adjacent vascular endothelium (47). Furthermore, circulating platelet microparticles have been detected in a variety of clinical syndromes of platelet activation. This raises the possibility that flow-dependent dispersal of platelet microparticles may represent a mechanism for transcellular effects of biologically active lipids, remote from the immediate microenvironment of their formation.

\section{Acknowledgments}

We are grateful for the technical assistance of Dr. Yu Min Shen and the advice of Drs. Aida Habib, Carlo Patrono, and Peter Davies.

This study was supported by a grant from the National Institutes of Health (HL-5800). Dr. FitzGerald is the Robinette Foundation Professor of Cardiovascular Medicine.

\section{References}

1. Armstrong, M.J., J. Storch, and N. Dainiak. 1988. Stimulating distinct plasma membrane regions gives rise to extracellular membrane vesicles in normal and transformed lymphocytes. Biochim. Biophys. Acta. 946:106-112.

2. Bos-Vreugdenhil, A.P., J.E. Poldermans, M.M. Ruitenbeek, A.V. Nieuw Amerongen, and P.A. Roukema. 1985. Study on membrane fragments released from the sublingual glands of the mouse during secretion in vitro and in vivo. J. Biol. Buccale. 13:317-332.

3. George, J.N., E.B. Pickett, S. Saucerman, R.P. McEver, T.J. Kunicki, N. Kieffer, and P.J. Newman. 1986. Platelet surface glycoproteins. Studies on resting and activated platelets and platelet membrane microparticles in normal subjects, and observations in patients during adult respiratory distress syndrome and cardiac surgery. J. Clin. Invest. 78:340-348.

4. Beaudoin, A.R., and G. Grondin. 1991. Shedding of vesicular material from the cell surface of eukaryotic cells: different cellular phenomena. Biochim. Biophys. Acta. 1071:203-219.

5. Holme, P.A., F. Brosstad, and N.O. Solum. 1995. The difference between platelet and plasma F XIII used to study the mechanism of platelet microvesicle formation. Blood Coagul. Fibrinolysis. 6: 302-310.

6. Bizios, R., L.C. Lai, J.A. Cooper, P.J. Del Vecchio, and A.B. Malik. 1988. Thrombin-induced adherence of neutrophils to cultured endothelial monolayers: increased endothelial adhesiveness. J.Cell. Physiol. 134:275-280.

7. Fourcade, O., M.F. Simon, C. Viode, F.L. Rugani, A. Ragab, B. Fournie, L. Sarda, and H. Chap. 1995. Secretory phospholipase $\mathrm{A}_{2}$ generates the novel lipid mediator lysophosphatidic acid in membrane microvesicles shed from activated cells. Cell. 80:919-927.

8. Tans, G., J. Rosing, M. Christella, L.G.D. Thomassen, M.J. Heeb, R.F.A Zwaal, and J.H. Griffin. 1991. Comparison of anticoagulant and procoagulant activities of stimulated platelets and platelet-derived microparticles. Blood. 77: 2641- 2648 .

9. Holme, P.A., N.O. Solum, F. Brosstad, M. Roger, and M. Abdelnoor. 1994. Demonstration of platelet-derived microparticles in blood from patients with activated coagulation and fibrinolysis using a filtration technique and Western blotting. Thromb. Haemostasis. 72:666-671.

10. Singh, N., C.H. Gemmell, P.A. Daly, and E.L. Yeo. 1995. Elevated platelet-derived microparticle levels during unstable angina. Can. J. Cardiol. 11: 1015-1021.

11. Sims, P.J., T. Wielder, C.T. Esmon, H.T. Weiss, and S.J. Shattil. 1989. Assembly of the platelet prothrombinase complex is linked to the vesiculation of the platelet plasma membrane. Studies in Scott syndrome: an isolated defect in platelet procoagulant activity. J. Biol. Chem. 264:17049-17057.

12. Nomura, S., M. Suzuki, K. Katsura, G.L. Xie, Y. Miyazaki, T. Miyake, H. Kido, H. Kagawa, and S. Fukuhara. 1995. Platelet-derived microparticles may influence the development of atherosclerosis in diabetes mellitus. Atherosclerosis. 116:235-240.

13. Praticò, D., L. Iuliano, F.M. Pulcinelli, P.P. Gazzaniga, M.S. Bonavita, and F. Violi. 1992. Hydrogen peroxide triggers activation of human platelets selectively exposed to nonaggregating concentrations of arachidonic acid and collagen. J. Lab. Clin. Med. 119:364-370.

14. Ogletree, M.L., D.N. Harris, R. Greenberg, M.F. Haslanger, and M. Nakane. 1985. Pharmacological actions of SQ 29,548, a novel selective thromboxane antagonist. J. Pharmacol. Exp. Ther. 234:435-441.

15. Walters, M.N., and D.A. Willoughby. 1965. Indomethacin, a new anti- 
inflammatory drug: its potential use as a laboratory tool. J. Pathol. Bacteriol. 90: 641-648.

16. Neubig, R.R., R.D. Gantzos, and R.S. Brasier. 1985. Agonist and antagonist binding to alpha 2-adrenergic receptors in purified membranes from human platelets. Implication of receptor-inhibitory nucleotide-binding protein stoichiometry. Mol. Pharmacol. 28:475-486.

17. Fukuoka, T., Y. Nakajima, M. Matsumoto, M. Segawa, H. Kanehiro, M. Hisanaga, T. Wada, and H. Nakano. 1990. Effect of a platelet activating factor antagonist (CV-6209) on shock caused by temporary hepatic inflow occlusion. Life Sci. 47:565-570.

18. Li, Q., and M.K. Cathcart. 1994. Protein kinase C activity is required for lipid oxidation of low density lipoprotein by activated human monocytes. $J$. Biol. Chem. 269:17508-17515.

19. Lindahl, T.L., R. Festin, and A. Larrson. 1992. Studies of fibrinogen binding to platelets by flow-cytometry: an improved method for studies of platelet activation. Thromb. Haemostasis. 68:221-225.

20. Lapetina, E.G., and W. Seiss. 1987. Measurement of inositol phospholipid turnover in platelets. Methods Enzymol. 141:176-192.

21. Bligh, E.G., and W.J. Dyer. 1959. A rapid method of total lipid extraction and purification. Can. J. Biochem. Physiol. 37:911-917.

22. Kaluzny, M.A., L.A. Duncan, M.V. Merrit, and D.E. Epps. 1985. Rapid separation of lipid classes in high yield and purity using bonded phase columns. J. Lipid Res. 26:135-140.

23. VanRollins, M., T.L. Kaduce, X. Fang, H.R. Knapp, and A.A. Spector. 1996. Arachidonic acid diols produced by cytochrome-P450. Monoxygenases are incorporated into phospholipids of vascular endothelial cells. J. Biol. Chem. 24:14001-14009.

24. Fischer, C., and J.C. Frolich. 1982. Analysis of prostanoids by GC/MS measurement. Adv. Lipid Res. 19:185-202.

25. Praticò, D., J.A. Lawson, and G.A. FitzGerald. 1995. Cyclooxygenase dependent formation of the isoprostane 8 epi- $\mathrm{PGF}_{2 \alpha}$. J. Biol. Chem. 270:98009808.

26. Hadley, J.S., A. Fradin, and R.C. Murphy. 1988. Electron capture, negative ion chemical ionization analysis of arachidonic acid. Biomed. Environ. Mass Spectrom. 15:175-178.

27. Jaffe, E.A., R.L. Nachman, C.G. Becker, and C.R. Minick. 1973. Culture of human endothelial cells derived from umbilical veins. Identification by morphological and immunological criteria. J. Clin. Invest. 52:2745-2756.

28. Habib, A., C. Creminon, Y. Frobert, J. Grassi, P. Pradelles, and J. Maclouf. 1993. Demonstration of an inducible cyclooxygenase in human endothelial cells using antibodies raised against the carboxyl-terminal region of the cyclooxygenase-2. J. Biol. Chem. 268:23448-23454.

29. Creminon, C., Y. Frobert, A. Habib, J. Maclouf, P. Pradelles, and J. Grassi. 1995. Immunological studies of human constitutive cyclooxygenase (COX-1) using an enzyme immunoreactive assay. Biochim. Biophys. Acta. 1254:333-340.

30. Praticò, D., E. Smyth, F. Violi, and G.A. FitzGerald. 1996. Local amplification of platelet function by 8 -epi prostaglandin $\mathrm{F}_{2 \alpha}$ is not mediated by thromboxane receptor isoforms. J. Biol. Chem. 271:14916-14924.

31. Hirata, M., Y. Hayashi, F. Ushikubi, Y. Yokota, R. Kageyama, S. Nakanishi, and S. Narumiya. 1991. Cloning and expression of cDNA for a human thromboxane $\mathrm{A}_{2}$ receptor. Nature (Lond.). 34:617-620.

32. Raychowdhury, M.K., M. Yukawa, L.J. Collins, S.H. McGrail, C.K Kent, and A. Ware. 1994. Alternative splicing produces a divergent cytoplasmic tail in the human endothelial thromboxane $\mathrm{A}_{2}$ receptor. J. Biol. Chem. 269: 19256-19261.

33. Praticò, D., and G.A. FitzGerald. 1996. Generation of 8-epi prostaglan$\operatorname{din} \mathrm{F}_{2 \alpha}$ by human monocytes. Discriminate production by reactive oxygen spe cies and prostaglandin endoperoxide synthase-2. J. Biol. Chem. 271:8919-8924.

34. Takahara, K., R. Murray, G.A. FitzGerald, and D.J. Fitzgerald. 1990. The response to thromboxane $\mathrm{A}_{2}$ analogues in human platelets. J. Biol. Chem. 265:6836-6844.

35. Hara, S., I. Kudo, H.W. Chang, K. Matsuta, T. Miyamoto, and K. Inoue. 1989. Purification and characterization of extracellular phospholipase $A_{2}$ from human synovial fluid in rheumatoid arthritis. J. Biochem. 105:395-399.

36. Seilhamer, J.J., W. Pruzanski, P. Vadas, S. Plant, J.A. Miller, J. Kloss, and L.K. Johnson. 1989. Cloning and recombinant expression of PLA 2 present in rheumatoid arthritic synovial fluid. J. Biol. Chem. 264:5335-5338.

37. Mayer, R.J., and L.A. Marshall. 1993. New insights on mammalian phospholipase $\mathrm{A}_{2}$ (s): comparison of arachidonoyl-selective and non-selective enzyme. FASEB J. 7:339-348.

38. Damron, D.S., D.R. Van Wagoner, C.S. Moravec, and M. Bond. 1993. Arachidonic acid and endothelin potentiate $\mathrm{Ca}^{2+}$ transients in rat cardiac myocytes via inhibition of distinct $\mathrm{K}^{+}$channels. J. Biol. Chem. 268:27335-27344.

39. Hallak, H., L. Muszbek, M. Laposata, E. Belmonte, L.F. Brass, and D.R. Manning. 1994. Covalent binding of arachidonate to $\mathrm{G}$ protein alpha subunits of human platelets. J. Biol. Chem. 269:4713-4716.

40. Stankova, J., and M. Rola-Pleszczynski. 1992. Leukotriene $B_{4}$ stimulates $\mathrm{c}$-fos and c-jun gene transcription and AP-1 binding activity in human monocytes. Biochem. J. 282:625-629.

41. Zembowicz, A., S.L. Jones, and K.K. Wu. 1995. Induction of cyclooxygenase-2 in human umbilical vein cells by lysophosphatidylcholine. J. Clin. Invest. $96: 1688-1692$.

42. Marcus, A.J., B.B. Weksler, E.A. Jaffe, and M.J. Broekman. 1980. Synthesis of prostacyclin from platelet-derived endoperoxides by cultured human endothelial cells. J. Clin. Invest. 66:9797-9806.

43. Marcus, A.J., M.J. Broekman, L.B. Safier, H.L. Ullman, N. Islam, C.N Serhan, and G. Weissman. 1984. Production of arachidonic acid lipoxygenase products during platelet-neutrophil interactions. Clin. Physiol. Biochem. 2:7883.

44. Marcus, A.J. Eicosanoid interaction between platelets, endothelial cells and neutrophils. 1990. Methods Enzymol. 187:585-599.

45. Lorant, D.E., G.A. Zimmerman, T.M. McIntyre, and S.M. Prescott 1995. Platelet-activating factor mediates procoagulant activity on the surface of endothelial cells by promoting leukocyte adhesion. Semin. Cell Biol. 6:295-303.

46. Miyazaki, Y., S. Nomura, T. Miyake, H. Kagawa, C. Kitada, H. Taniguchi, Y. Komiyama, Y. Fujimura, Y. Ikeda, and S. Fukuhara. 1996. High shear stress can initiate both platelet aggregation and shedding of procoagulant containing microparticles. Blood. 88:3456-3464.

47. Davies, P.F. 1995. Flow-mediated endothelial mechanotransduction. Physiol. Rev. 75:519-560. 